\title{
Effect of New Material and Production Technology Development on Food
}

\author{
E-tailing \\ Yukun LI ${ }^{1}$, Feng TAN ${ }^{1}$, Keith WALLEY², Yang XU1*, \\ ${ }^{1}$ Beijing University of Agriculture, China \\ 2 Harper Adams University, United Kingdom \\ ${ }^{*}$ Corresponding author
}

Key words: e-tailing; material and technology; food distribution; consumer behavior

\begin{abstract}
With the development of e-business technology and the policy support by the nation, industries has taken part in e-business and food industry is not an exception. E-tailing formats of food products is not only driving by general development of e-business in distribution channel, but also drive by adoption of new producing and packaging materials, and production technology development of food products. The technology development have effected on the food distribution in supply chain and influence final consumers' behavior in obtaining and consuming of food products in quantity, category and frequency etc.
\end{abstract}

\section{Introduction}

\section{New material and production technology impact on e-tailing in China}

Along with the new food producing materials (such as new food additives and new raw ingredient), packaging materials (such as fresh-keeping bag and chill bag) and production technology developing in China, people's expectations on food manufacturing and distribution are rising. Consumers pay more attention to products quality, convenience of shopping and time saving, especially when bad weather, traffic inconvenience, shopping rush hour are encountered, going to the supermarket become a headache. E-tailing can easily settle these problems. It provides consumers with convenience efficiency and economy [1]. By clicking the mouse, consumers can quickly browse the product information on the internet, choose from a wider scope, and save searching costs. In addition, the website runs 24 hours a day, consumer can choose and buy products at any time and place, which makes consumers have an unprecedented shopping elasticity $[2,3]$. Consumers who care for shopping convenience are more likely to choose online shopping [4,5], those who value their time more prefer shopping through the internet [6,7]. New materials applied in production and distribution has made standard, hygiene and safe of food products distributed via e-tailing become possible. At present, the consumer demand for online shopping become more and more strong.

\section{The development of food e-business in China}

\section{Increasing trade volume}

China online retail market traded 2.8211 trillion yuan in 2014, compared with that of 2013, 1.8851 trillion yuan, it has increased by $49.7 \%$. Although food e-business account for $3 \%$ for the whole e-business trade volume, it has a dramatic increase from 4.3 billion in 2009 to 32.4 billion in 2013 in figure 1[8]. The dramatic consumer need are resulted from three reasons. The first is the logistics 
system further improved. The second is the online payment methods and platforms, such as alipay, unionpay, applepay has a dramatic increase. The most important is network consumption habits preliminary formed for food industry in China [9].

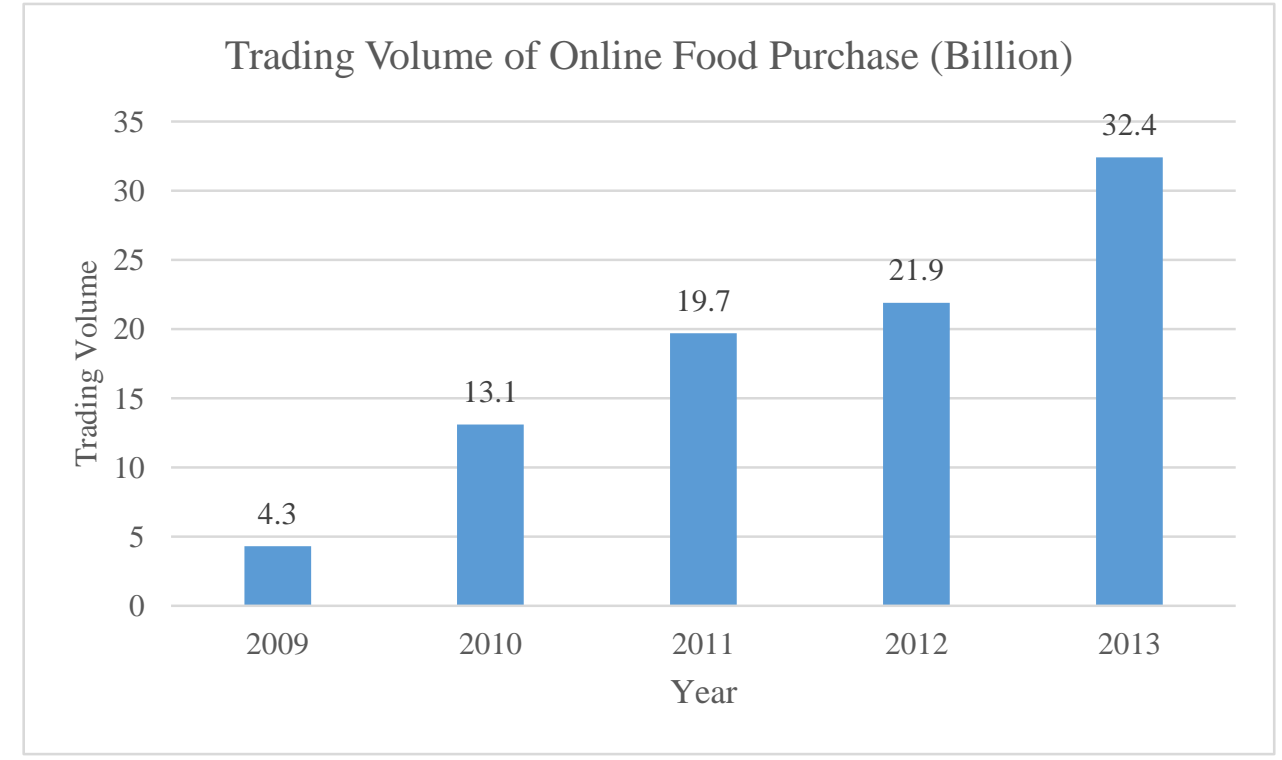

Figure1 Trading volume for online food purchase [8]

\section{New segment of market}

According to the report of 37th China internet network development statistic, up to December 2015, there are 688 million internet users in China, the young adults aged from 28 to 38 account for the highest proportion (46.94\%) [10]. As an important part of young adults, white collar has increasingly become the main groups of online shopping. The white collar fully command the networks technology and they have discretionary spending and pursuit personality and fashion. Advanced shopping concept and limited life spending make them become the mainstay of online shopping

\section{Methodology}

560 valid questionnaire have been used in analysis. Data are collected from two ways. 170 questionnaires handed out in different districts in Beijing, and 410 online survey collecting data from different provinces. Statistic, cross tabulation and chi-square test are applied in the SPSS software for data analysis.

\section{Result analysis}

\section{Respondents Statistic}

The results show in the table 1: in 560 samples, the proportion of female almost equals that of male. The age of the respondents mainly concentrated in the group of $28-38(40.4 \%)$. The people under 18 years old account for the least proportion. Among these samples, 93\% people experienced online food shopping. But most of them use online food shopping twice a month $(42.3 \%)$ or when discounting use it (46.5\%), that means the marketing pattern of online shopping just get started. But the payment method shows 53\% people use mobile pay to shop, which means the payment platform is very mature. In addition, for searching product details, $59.2 \%$ people use online text description, which is 4 times of seeing comments. And only $2 \%$ people use online enquiry. 
Table 1: Respondents statistics

\begin{tabular}{|c|c|c|c|c|c|}
\hline $\begin{array}{l}\text { Respondents } \\
\text { information }\end{array}$ & groups & percentage & $\begin{array}{l}\text { Respondents } \\
\text { information }\end{array}$ & groups & percentage \\
\hline \multirow[t]{2}{*}{ gender } & female & 51.4 & \multirow{2}{*}{$\begin{array}{l}\text { online food } \\
\text { shopping }\end{array}$} & yes & 93.0 \\
\hline & male & 48.6 & & no & 7.0 \\
\hline \multirow[t]{4}{*}{ age } & below18 & 7.1 & \multirow[t]{4}{*}{ salary } & Below 5000 & 39.4 \\
\hline & $18-28$ & 25.4 & & $5001-8000$ & 35.2 \\
\hline & $28-38$ & 40.4 & & $8000-10000$ & 15.5 \\
\hline & above38 & 27.1 & & Above10001 & 9.9 \\
\hline Purchase & 2 per week & 2.8 & \multirow{7}{*}{$\begin{array}{l}\text { ways for } \\
\text { product details }\end{array}$} & Online text & 59.2 \\
\hline \multirow[t]{3}{*}{ frequency } & 1 per week & 5.6 & & description & \\
\hline & 2 per months & 42.3 & & Online picture & 11.3 \\
\hline & discounting & 46.5 & & Online inquiry & 2.8 \\
\hline \multirow[t]{3}{*}{ Payment methods } & Ebank pay & 17 & & view comments & 16.9 \\
\hline & pay on delivery & 3 & & Brand reputation & 9.9 \\
\hline & Mobile pay & 51 & & & \\
\hline
\end{tabular}

\section{Purchasing situation towards food e-tailing}

From table 2, the survey indicates that when people shopping on-line, cookies \& pastry, nuts, chips, dried meat slice, chocolate ranked as the top five favorite food among 15 foods and fruit and vegetable only accounts for $16.5 \%$ which is only one third of cookies \& pastry. The reason could be fruits \& vegetables are more likely to damage and deterioration on delivery and it is convinced by the frequently problems which indicates damaging on the delivery is most focused issue (70.4\%). When the consumer had bad experience, $47.9 \%$ people do nothing to protect their own interest and only $22.5 \%$ people resort to law helping to get their refunding. This phenomenon could be explained by that online food supervision is not strictly so that the legitimate rights and interests of consumers are not guaranteed. Therefore, $39 \%$ consumers expect to strengthen the online food supervision to improving food e-business.

Table 2: Consumption attitude statistic

\begin{tabular}{|c|c|c|c|}
\hline \multicolumn{2}{|c|}{ Attitude to bad experience (multiple question) } & \multicolumn{2}{|c|}{ Measures improving food e-business (multiple question) } \\
\hline Do nothing & 47.9 & Strengthen supervision & 39.4 \\
\hline Contact the seller until problem settled & 22.5 & $\begin{array}{l}\text { Strengthen the protection of consumer } \\
\text { interests }\end{array}$ & 35.2 \\
\hline Law helping until refunding & 22.5 & $\begin{array}{l}\text { Raise the threshold of entering } \\
\text { the market }\end{array}$ & 21.1 \\
\hline $\begin{array}{l}\text { Won't use the shopping website and } \\
\text { comment bad experience }\end{array}$ & 7.0 & Optimization of logistics & 4.2 \\
\hline \multicolumn{2}{|c|}{ Preference of consumption(multiple question) } & \multicolumn{2}{|l|}{ Frequently problems (multiple question) } \\
\hline Cookies \& pastry & $49.3 \%$ & Damaging on delivery & $70.4 \%$ \\
\hline Nuts & $45.1 \%$ & Received expired food & $56.3 \%$ \\
\hline chips & $38.0 \%$ & Complex refund process & $40.8 \%$ \\
\hline dried meat slice & $33.8 \%$ & Unfavorable taste & $35.2 \%$ \\
\hline chocolate & $26.8 \%$ & Delivering wrong goods & $25.8 \%$ \\
\hline
\end{tabular}




\section{Key influence factors on satisfaction}

From table 3, the satisfaction with the brand has significantly influence on purchase frequency. When consumers online shop twice per month, $28.6 \%$ people are very satisfied with the purchase process. But when consumer increase the purchase frequency that they online purchase once per week, the proportion of consumers with very satisfaction dramatically increases $(57.1 \%)$. That means the satisfaction with the brand can significantly promote consumers' online food shopping. In order to further examine the relationship between buying frequency and brand satisfaction, chi-square test carried out in the SPSS software. The significant level of the chi-square test is 0.00 .

Table 3: Cross tabulation and Chi-square test for buying frequency and brand satisfaction

\begin{tabular}{|c|c|c|c|c|c|c|}
\hline $\begin{array}{l}\text { The satisfaction } \\
\text { with the brand }\end{array}$ & $\begin{array}{c}\text { Very } \\
\text { dissatisfaction }\end{array}$ & dissatisfaction & Neither & satisfaction & $\begin{array}{c}\text { Very } \\
\text { satisfaction }\end{array}$ & total \\
\hline 2 per week & $50.0 \%$ & $0.0 \%$ & $0.0 \%$ & $50.0 \%$ & $0.0 \%$ & $100.0 \%$ \\
\hline 1 per week & $0.0 \%$ & $0.0 \%$ & $0.0 \%$ & $42.9 \%$ & $57.1 \%$ & $100.0 \%$ \\
\hline 2 per months & $0.0 \%$ & $14.3 \%$ & $0.0 \%$ & $57.1 \%$ & $28.6 \%$ & $100.0 \%$ \\
\hline discounting & $2.6 \%$ & $2.6 \%$ & $26.3 \%$ & $47.4 \%$ & $21.1 \%$ & $100.0 \%$ \\
\hline \multicolumn{2}{|c|}{ Chi-Square Tests } & Value & $\mathrm{df}$ & \multicolumn{3}{|c|}{ Asymp. Sig. (2-sided) } \\
\hline \multicolumn{2}{|c|}{ Pearson Chi-Square } & $279.627^{\mathrm{a}}$ & 12 & \multicolumn{3}{|c|}{.000} \\
\hline \multicolumn{2}{|c|}{ Linear-by-Linear Association } & 4.155 & 1 & \multicolumn{3}{|c|}{.042} \\
\hline \multicolumn{2}{|c|}{$\mathrm{N}$ of Valid Cases } & 560 & & & & \\
\hline
\end{tabular}

Apart from the brand satisfaction, expiration satisfaction also has significantly impact on the buying frequency. It is evidenced from the data of table 4 that when people online purchase twice a month, $28.6 \%$ people are very satisfied with expiration. But when purchase frequency increases to once per week, the proportion of very satisfaction with expiration also grow to $42.9 \%$. And the relationship is further proved by chi-square test of these two variables, that the value of the test is 301.716 .

Table 4: Cross tabulation and Chi-square test for buying frequency and expiration satisfaction

\begin{tabular}{|c|c|c|c|c|c|c|}
\hline $\begin{array}{c}\text { The satisfaction } \\
\text { with expiration }\end{array}$ & $\begin{array}{c}\text { Very } \\
\text { dissatisfaction }\end{array}$ & dissatisfaction & Neither & satisfaction & $\begin{array}{c}\text { Very } \\
\text { satisfaction }\end{array}$ & total \\
\hline 2 per week & $50.0 \%$ & $0.0 \%$ & $0.0 \%$ & $50.0 \%$ & & $100.0 \%$ \\
\hline 1 per week & $0.0 \%$ & $0.0 \%$ & $0.0 \%$ & $57.1 \%$ & $42.9 \%$ & $100.0 \%$ \\
\hline 2 per months & $0.0 \%$ & $14.3 \%$ & $28.6 \%$ & $28.6 \%$ & $28.6 \%$ & $100.0 \%$ \\
\hline discounting & $2.6 \%$ & $2.6 \%$ & $23.7 \%$ & $57.9 \%$ & $15.8 \%$ & $100.0 \%$ \\
\hline \multicolumn{2}{|c|}{ Chi-Square Tests } & Value & df & & Asymp. Sig. (2-sided) \\
\hline Pearson Chi-Square & $301.716^{\mathrm{a}}$ & 12 & .000 & .001 \\
\hline \\
Linear-by-Linear Association
\end{tabular}




\section{Summary}

Development of e-tailing on food products is still in growing stage, although the payment platform is very mature. New materials used in food production and distribution have big impacts on on-line food selling, however, unstandardized, damaged, and poor quality food products are worrying on-line food shoppers. Now, the legitimate rights and interests of consumers are not guaranteed, so people do nothing to protect their own interest when experiencing bad purchase. In addition, online food purchase has its own feature compared with other online shopping. The satisfaction with brand and expiration can significantly influence the purchase frequency.

\section{Acknowledgement}

It was appreciated that the primary works are supported by a group of undergraduate student, Xiang Li et al.

\section{Reference}

[1] Miao Jing. Perceived risk research of online shopping. Shang Hai: Shanghai university of finance and economics press, 2006: 63-105.

[2] Lei Qi, Wenxian Sun. Research On Influential Factors Of Online Shopping: Based On Customer Satisfaction. Jiangsu Commercial Forum, 2016, (1):25-28.

[3] Ziqiang Wu. The empirical analysis of online shopping for influence factors. Statistics and Decision, 2015, (20):100-103.

[4] Childers, Terry L.,Christopher L. Carr,Joaxin Peck, Hedonic anutilitarian motivations for online retail shopping behavior. Journal of Retailing, 2001, 77,511-535.

[5] ]Bhatnagar, Amit, Sanjog Misra, and Raghav H. Rao. On risk, convenience and internet shopping behavior. Communications of the ACM, 2000, 43 (11), 98-105

[6] Sin, Leo and Alan Tse. Profiling internet shoppers in Hong Kong: Demographic, psychological, attitudinal and experiential factors-Journal of international Consumer Marketing, 15 (1), 2002.

[7] Sim, Loo Lee and Sze Miang Koi. Singapore's internet shoppers and their impact on traditional shopping patterns. Journal of Retailing and Consumer Services, 2002, 9,115-124.

[8] Yanru Chen, Jinguang Yang, Empirical Study of the Impacts on Behavior Intention of Online Food Purchase Based on Structural Equation Model. Journal of Southwest Jiaotong University (Social Sciences), 2014, (3):150-158.

[9] Weijun Liu. Consumers' Net Puschasing Cognitive for Food and Willingness to Pay through Micro Platform [J]. Food and Nutrition in China, 2016, 22(1):44-48

[10] Jianru Zhao. The analysis for online shopping food security. Modern Business, 2015, (32):11-12 